\title{
Literatos em escritórios de jornais: jornalismo, literatura e trabalho (1883-1908)
}

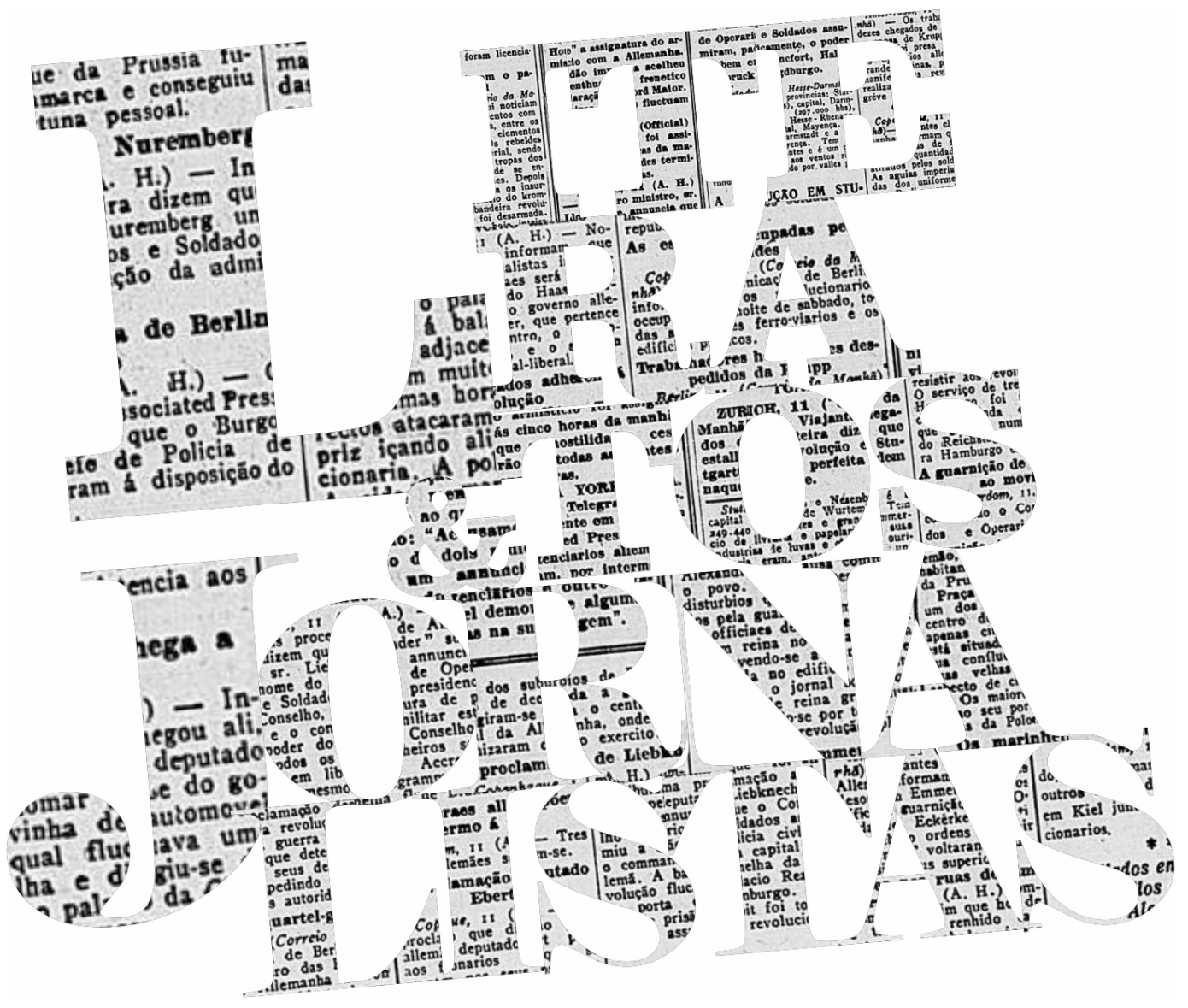

Tiras de jornais, s./d., fotografias, montagem.

\section{Gabriela Nery}

Mestre em História pela Universidade Federal de São Paulo (Unifesp). Doutoranda em História pela Universidade Estadual de Campinas (Unicamp). Professora da rede municipal de ensino de São Paulo. gabriela_nery@yahoo.com 


\section{Literatos em escritórios de jornais: jornalismo, literatura e trabalho (1883-1908)}

Writers in newspaper offices: journalism, literature and labour (1883-1908)

\section{Gabriela Nery}

\section{RESUMO}

Este artigo trata das transformações pelas quais passaram a imprensa e o jornalismo do Rio de Janeiro, entre as décadas de 1880 e 1900. Centralmente, foi colocada sob investigação a relação dos literatos com as empresas jornalísticas que se consolidaram no período, em especial os jornais diários. Nesse processo, analisaram-se algumas tentativas de definição da profissão dos jornalistas na capital, bem como a importância do trabalho para a produção literária de muitos homens de letras. $\mathrm{O}$ poeta, cronista e jornalista Olavo Bilac foi um dos sujeitos acompanhados com atenção, inclusive na criação de projetos literários pessoais como as revistas ilustradas. Foram tomadas como fontes crônicas publicadas na imprensa, registros no Almanak Laemmert e entrevistas veiculadas na coluna "O Momento Literário", de João do Rio.

PALAVRAS-CHAVE: jornalismo; literatura; trabalho.

\section{ABSTRACT}

This paper analyses the process of transformation that occurred in the press and journalism from Rio de Janeiro, between the 1880s and 1900s. Mainly, the relationship established between the literati and journalistic companies was under investigation, paying attention to the daily newspapers. Also, the attempts of defining journalism as a profession itself were analyzed in pair with the rising importance of the conception of labor to the literary production from lots of men of letters in the period. The poet, chronist, and journalist Olavo Bilac was one of the subjects followed with attention, including his literary personal projects as the illustrated magazines. The documents used for this research were chronicles published on the press, registers from Almanak Laemmert, and the interviews contained in $\mathrm{O}$ Momento Literário, from João do Rio.

KEYWORDS: journalism; literature; labour.

Quando chegou a vez de João Tesourinha ocupar as páginas da Gazeta de Notícias, em 9 de fevereiro de 1885, o cronista escolheu trazer em suas linhas não outra coisa senão suas impressões sobre a fundação do Club dos Jornalistas, na cidade do Rio de Janeiro.

Tesourinha, assim como Zig-Zag e Dr. Zig-Zug, eram pseudônimos usados por um dos redatores da Gazeta, o taquígrafo e teatrólogo português Henrique Chaves. Ele atuava no jornal ao menos desde 1877 e nem sempre de forma exclusiva, visto que por anos ofereceu seus serviços de taquigrafia para outras folhas, como o sisudo Jornal do Comércio e o Diário Oficial. Chaves também seria aquele que assumiria a Gazeta de Notícias após a morte de José Fer- 
reira de Souza Araújo - fundador da folha e condutor absoluto daquela redação por quase 25 anos. De todo modo, o que interessa assinalar por ora é que, exatamente no ano de 1885, Chaves já não dividia seu tempo com outros jornais, dedicando seu trabalho de jornalista à redação da Gazeta de Notícias. Ele também ocupava um assento na empreitada coletiva da escrita da série "Balas de Estalo", que contava com outros autores como Machado de Assis, Capistrano de Abreu, Demerval da Fonseca - seu colega de redação na Gazeta -, além do próprio Ferreira de Araújo. ${ }^{1}$ João Tesourinha, portanto, era um dos narradores-personagens que conduzia algumas das crônicas de Chaves nessa série, sendo este um artifício que extravasava em muito a ideia de simples ocultação de autoria.

Dito isso, naquele início de fevereiro, Tesourinha declarava pertencer ao grupo daqueles que tinham a maior confiança nos efeitos do Club dos Jornalistas, que viria para criar um laço sobre todos os "publicistas da nossa ter$\mathrm{ra}^{\prime}$, a ponto de imprimir à classe "o aspecto pitoresco e ao mesmo tempo apetitoso de uma formidável penca de bananas". ${ }^{2}$ Claro, umas mais verdes, outras mais maduras, mas de todo modo formidável. O manejo do humor como elemento constitutivo da crônica era patente, uma das características que, aliás, atravessava os demais colaboradores da série, e não é possível ficar alheia aos modos do narrador expor suas impressões. Nesse ritmo ele seguia, e se a um tempo, para além das bananas, tomava o conjunto dos publicistas como "duas dúzias de cavalheiros, de educação esmerada, que tem sobre os ombros o pesado encargo de doutrinar os povos"3, por outro alertava para certa propensão do grupo ao conflito, uma condição encarada como própria e interna à classe daqueles que trabalhavam na imprensa - habituados a contradizeremse por força do ofício.

Era desse duplo caráter que emergia o nó a ser desatado na trama de fundação do Club dos Jornalistas, de acordo com João Tesourinha. De que maneira seria possível forjar uma unidade dentre os educadíssimos publicistas da terra, que assumiam o fardo civilizacional contido no exercício do jornalismo e se viam, ao mesmo tempo, em constante contenda interna? Ele, então, colocava às claras suas apreensões:

Não sei se me explico claramente. Aí vai a cousa mais por miúdo:

Eu redijo um jornal; o Escaravelho dá-me uma bicada, no intuito de sacudir a mosca; eu perco a pouca delicadeza peculiar à nossa classe, e num rapto de penna digo no dia seguinte: O Escaravelho é um alho.

Pergunto eu: qual a atitude do club? Obrigar-me-á a lei social a engolir o alho, sob pena de ser excluído do grêmio e perder os meus títulos de jornalista, ou imporá o estatuto do club a Escaravelho a obrigação de me quebrar a cara, para corrigir minha insolência?

${ }^{1}$ Cf. RAMOS, Ana Flávia Cernic. Política e humor nos últimos anos da Monarquia: a série "Balas de Estalo" (1883-1884). Dissertação (Mestrado em História) - Unicamp, Campinas, 2005, e idem, As máscaras de Lélio: ficção e realidade nas "Balas de Estalo" de Machado de Assis. Tese (Doutorado em História) - Unicamp, Campinas, 2010.

2 Balas de Estalo. Gazeta de Notícias, Rio de Janeiro, 9 fev. 1885, p. 2.

${ }^{3}$ Idem. 
Hipóteses como estas que eu acabei de formular, têm aparecido e hão de aparecer aos milhares, e portanto afiguram-se-me dignas de ser contempladas na nossa lei social.

Espero, pois, que a comissão não as desprezará. ${ }^{4}$

Para lidar com situações como estas, as atenções e sugestão do narrador encontravam algum remédio na formulação dos estatutos que regeriam o grupo, a cargo de uma comissão de notáveis composta por Quintino Bocaiúva, Ferreira de Araújo, José do Patrocínio, Valentim Magalhães e Manoel Carneiro. ${ }^{5} \mathrm{Na}$ visão de Tesourinha, o melhor a fazer no caso da fundação de uma associação de jornalistas seria elaborar suas leis sociais de modo mais casuístico possível, que não se limitasse aos modelos das associações de outros ofícios e se concentrasse nas particularidades daquela classe, o que poderia evitar os problemas como os enunciados acima. "Cada terra com seu uso cada roca com seu fuso", repisava. ${ }^{6}$

As intenções de fundação do Club, aqui pontualmente apresentadas entre o humor e as preocupações de João Tesourinha, foram assunto que figurou na imprensa do Rio de Janeiro durante alguns anos - em crônicas, comentários e notícias diversas. As linhas do narrador são, portanto, parte desse conjunto e delas saltam elementos valiosos que servem como meio de aproximação ao jornalismo da década de 1880, que passava por mudanças importantes, principalmente no que se refere às folhas diárias. Dentre alguns pontos, dois aspectos da crônica valem a atenção mais detida. O primeiro reside na nada fortuita caracterização daqueles que poderiam tomar parte no Club dos Jornalistas, as duas dúzias de cavalheiros educados e incumbidos de atuar como farol da civilização, identificando os inimigos da sociedade. Para retomar metáfora utilizada na crônica, a penca de bananas poderia comportar jornalistas experientes ou novatos, mas no limite deveria fazer-se entre iguais, sob parâmetros estabelecidos.

O outro aspecto que vale destacar diz respeito à ênfase a uma suposta singularidade da classe dos jornalistas e, portanto, à sugestão de tomar alguma distância de outras experiências associativas que ganhavam fôlego", "de outras sociedades do mesmo gênero" ${ }^{\prime}$, para criar um estatuto que de algum modo captasse as peculiaridades daqueles que, em sua faceta mais evidente, esquivavam-se de qualquer alusão a serem tomados como trabalhadores.

O contexto no qual se deu a proposta de criação do Club, então, vem a calhar e delineia muitas das intenções contidas no projeto. A iniciativa teria partido de Quintino Bocaiúva, então diretor d'O País, para enredar parte da imprensa em um mesmo conjunto de práticas e moralidades que a circunscrevesse, ao passo que deliberadamente deixava de fora uma série de outros sujeitos e seus periódicos, que povoavam as ruas do Rio de Janeiro no início da

${ }^{4}$ Idem.

${ }^{5}$ Club dos Jornalistas. O País, Rio de Janeiro, 5 fev. 1885, p. 1.

${ }^{6}$ Balas de Estalo, op. cit.

7 Para dados precisos sobre o crescimento do associativismo no Segundo Reinado, ver MAROTTA, Marconni Cordeiro. As sociedades do Império: política, economia e associativismo beneficente no Rio de Janeiro do Segundo Reinado. Dissertação (Mestrado em História) - UFF, Niterói, 2015.

${ }^{8}$ Cf. Balas de Estalo, op. cit. 
década de 1880. Neste último grupo destacavam-se os pasquins, folhas de menor estrutura e circulação que escapavam às condutas dos grandes jornais diários. Eles tinham repercussão principalmente por terem se especializado na polêmica em nível contundente, lançando mão da calúnia e da crítica virulenta como forma de circular e lucrar. ${ }^{9}$ Seu maior representante foi O Corsário, do jornalista, tipógrafo e liberto Apulco de Castro, assassinado nas ruas da capital em 1883, após publicar ofensas ao $1^{\circ}$. Regimento de Cavalaria da Corte. ${ }^{10}$

É possível considerar, assim, que a preocupação de sujeitos como o diretor d'O País em normatizar e determinar, de algum modo, a atividade jornalística naqueles anos é indício da efervescência e da multiplicidade da imprensa do período. Dessa maneira, a iniciativa apontava para as dinâmicas expansivas do espaço público da Corte em seus últimos anos, pautadas pelo crescimento da cidade e pelo alargamento de seus circuitos de comunicação. Eles se materializavam na fundação de inúmeras publicações, muitas vezes bastante efêmeras, na fundação de associações literárias e de instrução, no boca a boca dos cafés, nos panfletos e pasquins passados de mão em mão, ou nos tradicionais jornais diários e revistas semanais. A fundação do Club dos Jornalistas, portanto, buscava dar contornos mais explícitos ao ofício e reivindicar a prerrogativa de dizer quem dele poderia ou não participar. Curiosamente, quem sabe às voltas com as questões enunciadas por João Tesourinha, o Club nunca saiu do papel. De qualquer maneira, a iniciativa não deixou de ser percebida pelos pasquins, e os comentários publicados no Carbonário, ainda em 1883, mostram que estavam atentos:

Eu appaudo [sic] a idéia do tal club, contando [sic] que ele antes que tudo seja uma verdade. Ele se deverá compor de todos os jornalistas e panfletistas que a ele queiram pertencer.

Sendo assim há toda a razão que se funde tão útil instituição. Ela é uma necessidade. A nossa adesão ao club não vai, porém ao extremo da condescendência, e não poderemos suportar, que, por exemplo dele faça parte o Serpa, um sujeito que usurpa o título de jornalista, pelo simples fato de ser qualquer cousa da "Gazeta Preta".

Entenda-mo-nos [sic] - clube dos jornaleiros, não clube dos jornalistas ou dos pedantes: de todos os que escrevem jornais.

Sendo assim, conte também conosco. ${ }^{11}$

Era explícito que os carbonaristas reconheciam o intuito restritivo do Club e é possível que encarassem a empreitada também em perspectiva ampliada, como uma conjugação dos mais importantes veículos jornalísticos para ditar os rumos de uma imprensa em expansão, investindo contra à proliferação de pequenos periódicos e panfletos, como o próprio Carbonário. Os comentários feitos pelo pasquim, inclusive, deixavam ver muitas das indisposições, não passando desapercebida a referência virulenta e racista a José do Patrocínio, que não só compunha a comissão para organização dos estatutos do Club

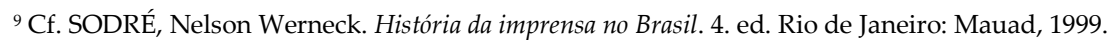

${ }^{10}$ Cf. ARAÚJO, Rodrigo Cardoso Soares de. Pasquins: submundo da imprensa na Corte Imperial (18801883). Dissertação (Mestrado em História) - UFRJ, Rio de Janeiro, 2009. Ver também HOLLOWAY, Thomas $\mathrm{H}$. The defiant life and the forgotten death of Apulco de Castro: race, power, and historical memory. Estudios Interdisciplinarios de América Latina, v. 19, n. 1, Tel Aviv, 2008.

${ }^{11}$ Cavaquinhos. Carbonário, Rio de Janeiro, 27 jul. 1883, p. 2. 
como, de fato, comandava a Gazeta da Tarde desde a morte de seu fundador, o reconhecido advogado, escritor e jornalista negro Ferreira de Menezes. ${ }^{12} \mathrm{~A}$ publicação também sugeria uma mudança sugestiva no nome da associação, que deveria passar de "dos jornalistas" a "dos jornaleiros", para incorporar todos aqueles que dela quisessem tomar parte, pondo às claras as percepções de cada um dos grupos. É possível vislumbrar um aceno à questão de classe nessa sugestiva alteração. Por fim, após proporem modificações que colocariam por terra o intuito principal da iniciativa, o pasquim findava, quase gracejando, que acatadas as sugestões, contassem com eles.

Vê-se, a partir desse cenário, que ser jornalista no Rio de Janeiro das últimas décadas do século XIX era engajar-se em um ofício que passava por turbulências e transformações, e por isso engendrava muitas disputas sobre suas prerrogativas. Os próprios usos da categoria começariam a ganhar contornos mais explícitos justamente a partir da década de 1880, atrelado a uma acepção cada vez mais profissionalizada, o que pode ser visto não apenas nas tensões que circundaram o processo fracassado de fundação do Club dos Jornalistas, mas também nas publicações que se detinham sobre a vida mercantil, industrial e administrativa da cidade, notadamente o Almanak Laemmert.

Foi a partir precisamente de 1883, ano do assassinato de Apulco de Castro e quando se aventou a criação do Club pela primeira vez, que a profissão jornalista começou a aparecer de maneira mais corrente e consistente na sessão "Indicador" do Almanak, onde se ordenava e se apresentavam os diversos profissionais da Corte pelo nome, profissão e endereços. Assim, homens de letras que há décadas exerciam funções de direção ou ocupavam há tempos os escritórios dos periódicos, finalmente começaram a ter incorporada a categoria jornalista como profissão, ao lado de seus outros títulos: advogados, médicos, engenheiros, funcionários públicos. É importante perceber que o procedimento era uma novidade notável, especialmente pela própria especialização do Almanak Laemmert em ordenar e dispor os mais diversos grupos profissionais e atividades econômicas em suas páginas.

Essa emergência do jornalismo como profissão referenciável reafirma os indícios de que uma mudança estava em curso. Seguindo o mesmo fio, a década de 1890 viu esse movimento ganhar corpo, e o caso do renomado Dr. Ferreira de Araújo, médico e fundador da Gazeta de Notícias, é emblemático. Ele só seria referenciado pela primeira vez como jornalista, na sessão "Indicador" do Almanak, em 1891¹3, 16 anos após atuação constante em seu jornal. O mesmo aconteceu com uma série de outros sujeitos com longa carreira jornalística, como José do Patrocínio, Quintino Bocaiúva, Arthur Azevedo e o então inexperiente Olavo Bilac.

Dessa maneira, é importante dar destaque para a última década do século XIX como anos cruciais da formação de um novo entendimento e exercício do ofício do jornalista no Brasil, ocorrido no rastro do processo de conversão dos principais jornais diários da capital, agora da República, em empresas jornalísticas. O País, a Gazeta de Notícias e o Jornal do Comércio foram alguns dos

\footnotetext{
12 Ver PINTO, Ana Flávia Magalhães. Escritos de liberdade: literatos negros, racismo e cidadania no Brasil Oitocentista. Campinas: Editora da Unicamp, 2018.

${ }_{13}$ Almanak Administrativo, Mercantil e Industrial do Rio de Janeiro, 48. ano, 1891, p. 162.
}

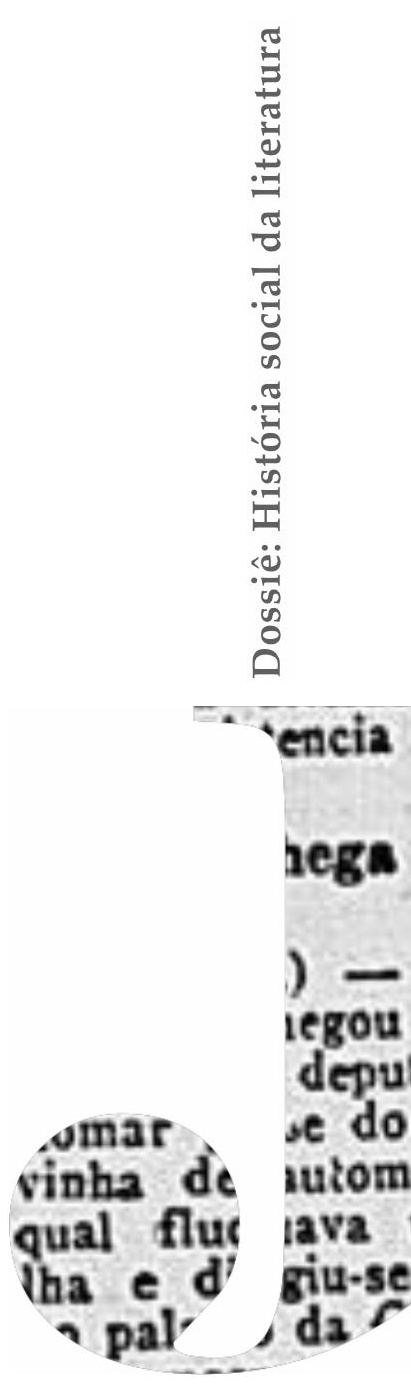


que, nesses anos, se transformaram em sociedade anônima ou de comandita, além de possuírem capital considerável e expandirem-se a passos largos. Um exemplo elucidativo, mais uma vez, está na Gazeta de Notícias, que em 1891 foi vendida e passou a constituir uma sociedade anônima. Naquele ano ela foi avaliada em 2.000:000\$000 (dois mil contos de réis) ${ }^{14}$, um aumento de mais de $400 \%$ em relação a seu valor de dois anos antes, 500:000\$000 (quinhentos contos de réis). ${ }^{15}$ Se for tomado como base o valor investido na ocasião da sua fundação, em 1875 , a valorização era de $6500 \%{ }^{16}$

A Gazeta é apenas um dos fios possíveis para se acompanhar dentro de um amplo movimento, que atingiu tanto as folhas diárias já existentes quanto as que seriam fundadas, como o Jornal do Brasil, de 1891. Emergia, assim, uma imprensa de caráter cada vez mais empresarial, ligada ao mercado da informação e da publicidade, e que demandaria novas composições dos quadros de trabalho e do regime de colaboração dos literatos. Eram nessas novas folhas que eles continuariam a cavar seus espaços, o que lhes demandaria novas funções.

\section{Permanências nas folhas, novidade nas redações: os literatos e o trabalho na imprensa diária}

“O jornalismo, especialmente no Brasil, é um fator bom ou mau para a arte literária?". Era com essa pergunta que João do Rio finalizava, ainda nos primeiros anos do século XX, cada uma das entrevistas que fez com alguns dos principais nomes da literatura no Rio de Janeiro, com pretensões de analisar as letras nacionais. Elas foram publicadas, cada uma à sua vez, a partir do ano de 1905, na Gazeta de Notícias, numa coluna intitulada “O Momento Literário". Posteriormente, os inquéritos foram organizados em conjunto e editados em livro, que veio a público pela editora Garnier sob o título de O momento literário, em $1909 .{ }^{17}$

Entre os muitos sujeitos escolhidos para tomar parte no inquérito, incluindo aqueles que se recusaram terminantemente ou evasivamente a respondê-lo, encontrava-se apenas uma mulher, Julia Lopes de Almeida. Ela recebeu João do Rio em sua casa na companhia de seu marido, o também escritor Filinto de Almeida. Acabou que a entrevista se tornou um misto das respostas dos dois literatos, Filinto e Júlia, e os comentários derradeiros sobre o papel da imprensa na literatura nacional viriam, de modo invertido, logo no começo da conversa. Isso porque João do Rio remetia com antecedência um mesmo conjunto de perguntas aos seus entrevistados e ia colher o que pudesse depois, por carta ou em visita pessoal. Nesse caso, o jornalista foi à residência dos Almeida ${ }^{18}$ no bairro de Santa Tereza e, no mosaico das falas dos dois

\footnotetext{
${ }^{14}$ Cf. Arquivo Nacional do Rio de Janeiro, Fundo da Junta Comercial do RJ, “Sociedade Anônima ‘Gazeta de Notícias'", livro 49, registro 1200, 1891.

${ }^{15}$ Cf. Contratos comerciais. Diário do Comercio, Rio de Janeiro, 30 maio 1889, p. 3.

${ }^{16}$ Cf. Gazeta de Notícias, Rio de Janeiro, 2 ago. 1917, p. 1 [autor ilegível].

${ }^{17}$ Cf. Binóculo. Gazeta de Notícias, Rio de Janeiro, 19 jan. 1909, p. 3.

${ }^{18}$ Julia Lopes de Almeida compunha o grupo que se reunia na sede da Revista Brasileira e que idealizou a fundação da Associação Brasileira de Imprensa (ABI). Entretanto, no momento de se definir os estatutos da academia, os literatos preferiram seguir à risca seu exemplo francês e deixaram de fora a presença de
} 
escritores, narradas por João do Rio a seu modo, a resposta sobre os impactos da imprensa na literatura foi dada justamente por Filinto, simbolicamente num momento em que a escritora havia se ausentado para cuidar de um dos filhos. A questão foi brevemente retomada um pouco depois, mas vale nos atermos às considerações de um dos membros fundadores da Academia Brasileira de Letras: “Tens no teu questionário uma pergunta a respeito da influência do jornalismo. Nós todos somos um resultado do jornalismo. Antes da geração dominante não havia bem uma literatura. $\mathrm{O}$ jornalismo criou a profissão, fez trabalhar, aclarou o espírito da língua, deu ao Brasil os seus melhores prosadores. Não é em geral um fator bom para arte literária, e talvez no Brasil não seja muito em breve, mas já foi e ainda o é".$^{19}$

A posição de Filinto de Almeida não era rara. Muitos dos literatos do início do século $\mathrm{XX}$ viam na imprensa um lugar fundamental, senão para elevar as letras nacionais, ao menos como local de trabalho, produção e circulação literária expressivos. Tal relevância não vinha de um reconhecimento recente do jornalismo para o exercício da literatura, tampouco era meramente uma opção secundária, aquilo que sempre restou aos literatos que não conseguiam publicar seus livros, ecoando alguns dos lamentos de uma categoria às voltas com o mercado e a classe editorial. Em sentido mais amplo, o jornalismo que se formava entre as décadas de 1880 e 1900 era resultado direto da configuração e expansão de um mercado das letras e da informação, materializadas de forma concreta nos veículos de imprensa, reestruturando-os gradativamente. ${ }^{20}$ Esse processo criou novas rotinas, espaços e demandas de trabalho possíveis de serem apropriados pelos literatos: e muitos deles o fizeram, com maior ou menor entusiasmo.

Foi também nesse mundo urbano em emergência, um Rio de Janeiro circunscrito, das impressoras rotativas, dos bondes, dos telégrafos e das agências de notícias, em que a informação circulava em ritmo cada vez mais acelerado e em caráter cada vez mais perecível, que um gênero literário bastante conhecido da imprensa, diária ou semanal, fincou alicerces ainda mais profundos em suas estruturas: a crônica aumentaria seus domínios e prestígio.

Esse tipo de produção literária, que há muito ocupava os jornais, se tingiu sem constrangimentos com as cores da modernidade - ideia tão em voga no final do século XIX e que avançou sobre o novecentos - e se adaptou com tamanha plasticidade ao jornalismo emergente do período republicano que abrigou em suas fileiras escritores dos mais diversos tipos, inclusive renomados poetas. Por outro lado, é preciso ressalvar como esses novos fazeres e temporalidades pesaram de maneira inversa sobre a atividade literária das mulheres nos jornais, e é possível perceber tais restrições através das palavras de Júlia Lopes de Almeida. Ela teve a oportunidade de comentar, ainda no inquérito literário respondido a João do Rio, sobre a impossibilidade de conciliar o trabalho nos jornais, especialmente como cronista, com seus outros afa-

mulheres. Assim, Filinto de Almeida foi convidado para ocupar o lugar da esposa. Ele era inclusive tratado como "acadêmico consorte", por conta das circunstâncias em que se deu sua indicação.

${ }^{19}$ DO RIO, João. O momento literário. Rio de Janeiro-Paris: H. Garnier, 1909, p. 29 e 30.

${ }^{20}$ Cf. PEREIRA, Leonardo Affonso de Miranda. Negociações impressas: a imprensa comercial e o lazer dos trabalhadores no Rio de Janeiro da Primeira República. História, v. 35, n. 99, São Paulo, 2016. 
zeres. As ponderações se deram quando, então, respondia sobre a forma como elaborava seus romances:

Aos poucos, devagar, com o tempo. Já não escrevo para os jornais porque é impossível fazer crônicas, trabalhos de começar e acabar. Idealizo o romance, faço o canevas dos primeiros capítulos, tiro uma lista dos personagens principais, e depois, hoje algumas linhas, amanhã outras, sempre consigo acabá-lo. Há uma certa hora do dia em que as coisas ficam mais tranquilas. É a essa hora que escrevo, em geral depois do almoço. Digo às meninas: - Fiquem a brincar com os bonecos que eu vou brincar um pouco com os meus. Fecho-me aqui, nesta sala, escrevo. Mas não há meio de esquecer a casa. Ora entra uma criada a fazer perguntas, ora é uma das crianças que chora. Às vezes não posso absolutamente sentar-me cinco minutos, e é nestes dias que sinto uma imperiosa, uma irresistível vontade de escrever... ${ }^{21}$

Os novos manejos do tempo talvez tenham sido das facetas mais destacadas a emergir no jornalismo do período, junto com sua crescente mercantilização, que imporiam restrições e parâmetros renovados às notícias e à literatura veiculadas nas páginas da imprensa. A esse cenário, permeado pela retórica da urgência das comunicações, misturavam-se outros discursos como o da precisão e da imparcialidade dos fatos, temperados pela inegável importância da publicidade para os dividendos sobretudo dos jornais diários.

As considerações feitas por Júlia Lopes de Almeida, assim, resvalavam em algo que podia ser encontrado sem muito esforço entre jornais e jornalistas daqueles anos. Eram novos tempos que demandavam rapidez na produção, especialmente das crônicas, além da capacidade de acompanhar não apenas as páginas dos jornais, que eram a própria matéria-prima do cronista, mas também a circulação intensa de informações que viajavam entre as redações, reuniões e mesas de cafés - como parte de uma performance do mundo das letras. Esse era um conjunto de disponibilidades bastante raro às mulheres do período, ou, melhor dizendo, disponível à uma parcela de indivíduos bastante restrita do período. Julia Lopes de Almeida declarava, então, ter abandonado a crônica, mas manteve-se como romancista, ainda explorando a possibilidade de aparecer nos folhetins. Na ocasião de seu inquérito literário, ela já havia publicado doze livros.

Em sentido quase oposto, outro ilustre entrevistado por João do Rio compôs carreira mesclando sua produção literária entre livros e periódicos, com destaque crescente para a atuação nesse último campo. Era ele Olavo Bilac. O poeta foi capaz de fiar-se no sucesso de suas poesias, publicadas em 1888 com repercussão largamente positiva na imprensa, e aproveitar o prestígio de ser visto como uma promessa que se cumpria no mundo das letras. ${ }^{22}$ Na ocasião ele tinha apenas 23 anos e já havia se colocado em ao menos duas grandes empreitadas que não chegaram a ser concluídas: a primeira, a Faculdade de Medicina, no Rio de Janeiro, e posteriormente a Faculdade de Direito, em São Paulo. Após abandonar as duas formações, ele se fixou na capital do

\footnotetext{
${ }^{21}$ DO RIO, João, op. cit., p. 31.

22 Ver Notas à margem. Gazeta da Tarde, Rio de Janeiro, 2 out. 1888, p. 2; Poesias de Olavo Bilac. Cidade do Rio, Rio de Janeiro, 27 set. 1888, p. 2; Contemporâneas. Gazeta de Notícias, Rio de Janeiro, 28 set. 1888, p. 2.
} 
Império e rapidamente travou relações sólidas com outros homens de letras da cidade, num grupo que ficou conhecido como a "geração boêmia". ${ }^{23}$

A figura do renomado jornalista José do Patrocínio e sua Cidade do Rio eram ponto central para o qual convergiam os tais "boêmios". Pardal Mallet, que no mesmo ano de 1888 era secretário de redação do diário ${ }^{24}$, Coelho Netto, Valentim Magalhães, Emílio de Menezes, Aluísio de Azevedo e Paula Ney eram alguns dos que frequentavam esse círculo, além do próprio Bilac. Tinham, dessa forma, suas atividades literárias largamente noticiadas nas páginas da Cidade - mas não apenas dela -, além de menções sobre participações em eventos diversos, publicações de crônicas e poesias, bem como referendavam-se e atuavam de forma bastante coesa nos círculos literário e jornalístico da cidade. As relações entre esses sujeitos se desdobravam, portanto, por espaços que extrapolavam em muito as folhas do jornal, ocupando outros locais que eram imprescindíveis para o desenvolvimento de suas atividades, como as conferências literárias, associações, meetings e cafés. ${ }^{25}$

Tal perspectiva pode ser evidenciada em um evento de formato bastante recorrente no período, acontecido no Teatro Recreio Dramático, em 19 de agosto de 1888. Nele, buscava-se uma ação beneficente em favor de um violinista e a primeira parte da programação se dava com a participação central de José do Patrocínio, secundada pelos demais literatos:

\section{Theatro Recreio Dramático}

HOJE, domingo 19 de agosto.

- Grande festival literário, musical e dramático, organizado por Luiz Murat e Frederico do Nascimento, em benefício do grande violinista português Pereira da Costa, que se acha há dois meses enfermo.

$1^{a}$. Parte. - Discurso oficial por José do Patrocínio

PARTE LITERÁRIA. - Preenchida pelos Srs. Luiz Delfino, Olavo Bilac, Osório Duque Estrada, Arthur Azevedo, Coelho Netto, Valentim Magalhães, Pardal Mallet, Oscar Rosas, Guimarães Passos, Luiz Murat e Paula Ney. ${ }^{26}$

A chegada de Olavo Bilac nos escritórios da Cidade do Rio assinalou uma mudança na sua trajetória, em que ele passou da atuação em pequenos periódicos acadêmicos para um jornal substancialmente mais expressivo, sob as vistas de um jornalista tanto mais experimentado quanto destacado. No correr desse caminho inicial, que alcançou a década de 1890, era possível topar com seus sonetos e poesias em folhas diversas como A Semana, de Valentim Magalhães, o Diário de Notícias, da Carneiro, Senna e Comp., e a Quinzena, dirigida por Jorge Pinto e Alfredo Pujol. Também era fácil encontrá-lo ora como orador, ora como recitador de poesias em reuniões das mais diversas e, enfim, ocupando a redação da revista $A$ Rua, fundada por Pardal Mallet, em 1889.

\footnotetext{
23 Ver RODRIGUES, João Paulo. A geração boêmia: vida literária em romances, memórias e biografias. In: CHALHOUB, Sidney e PEREIRA, Leonardo. A história contada: capítulos de história social da literatura no Brasil. Rio de Janeiro: Nova Fronteira, 1998, e BALABAM, Marcelo. Estilo moderno: humor, literatura e publicidade em Bastos Tigre. Campinas: Editora da Unicamp, 2017 (e-book), esp. o capítulo Muito talento, posição 212-789.

${ }^{24}$ Cf. Cidade do Rio, Rio de Janeiro, 7 ago. 1888.

${ }_{25}$ Cf. BALABAM, Marcelo, op. cit.

${ }^{26}$ Gazeta de Notícias, Rio de Janeiro, 19 ago. 1888, p. 6.
} 
Entretanto, foi como parte do jornal de Patrocínio que Bilac passou a se profissionalizar como jornalista - ofício o qual abraçou por quase duas décadas e se afastou apenas em momentos de exceção, como em seu exílio na cidade de Ouro Preto durante o governo de Floriano Peixoto.

A trajetória e a produção de Olavo Bilac dão acesso privilegiado a uma parte do cotidiano dos homens de letras, dos fins do oitocentos e início do novecentos. Como jornalista e literato de destaque, teve seus passos e textos e poesias em muito registrados, o que permite uma aproximação à sua produção literária e profissionalização na imprensa. Colocar tais aspectos sob análise, portanto, é um exercício capaz de pôr às vistas a então inédita e gradativa normalização do trabalho dos literatos nos escritórios dos diários, o que merece destaque porque dela emerge uma nova conotação, para a classe dos que escreviam, a do trabalho em uma acepção mais estrita do sustento, do salário, da reprodução das condições de vida. Dessa maneira, colocam-se também lentes mais minuciosas sobre as enunciações da escrita como atividade diletante, como exercício da ilustração por si ou como pura performance de um éthos bacharelesco, estampado nas folhas das publicações.

Muitos literatos ocuparam postos de trabalho nos escritórios dos jornais, como eram chamadas as redações, estabelecendo um vínculo diverso do de colaboradores eventuais e atendendo à demanda das nascentes empresas jornalísticas por trabalhadores especializados. Numa dupla acepção, a imprensa mantinha-se, então, como um atrativo aos que almejavam um local para emplacar suas produções literárias, o que não era novidade, mas ela também engendrava essa nova faceta, como um local de trabalho pronunciado, convertendo-se em possibilidade profissional materializada, também, no ofício do jornalista - e isso era uma novidade em relação à imprensa gestada durante grande parte do século XIX. Olavo Bilac versou sobre essa seara em muitas de suas crônicas, numa postura que transicionou gradativa e claramente, como revela seu texto de 1897 :

Ninguém escreve unicamente pela satisfação de escrever. Quem assina estas linhas já uma vez disse, num soneto, que não fazia versos

ambicionando

Das néscias turbas os aplausos fúteis;

Mas isso foi uma descaradíssima mentira rimada. Quem escreve, quer os aplausos fúteis das turbas néscias, e quer ainda ver pago o seu trabalho, não só em louvores, mas também em dinheiro. Escrever por escrever é platonismo, que, como todos os platonismos, é inepto e ridículo. ${ }^{27}$

Na ocasião, Bilac escrevia para o periódico A Bruxa, do qual era redator-chefe e proprietário, junto com Julião Machado. A revista semanal teve duração de aproximadamente dois anos e, nela, o jornalista explorou largamente sua atividade literária como cronista, guiado por uma postura livre e incisiva sobre diversos assuntos, entre eles os debates sobre os direitos autorais, o questionamento à atividade das casas editoriais, a defesa do trabalho ${ }^{27}$ A Bruxa, jan. 1897, apud DIMAS, Antonio. Bilac, o jornalista: ensaios. São Paulo-Campinas: Imprensa
Oficial/Edusp/Editora da Unicamp, 2002, p. 54. 
dos escritores de maneira ampla, além do apoio à criação de uma associação de caráter previdenciário para os que trabalhavam na imprensa. ${ }^{28}$

Como o próprio trecho acima evidencia, essa não foi uma postura constante, mas que progrediria como pauta nos escritos de Olavo Bilac, quanto mais imergia nas experiências de seu trabalho. Tal postura, inclusive, não se encerrava nas linhas remetidas para jornais e revistas, sendo ele assíduo em iniciativas que buscavam assegurar direitos ao conjunto dos homens de letras, como a Academia Brasileira de Letras, de 1897 e a Associação Brasileira de Homens de Letras, de 1914, para citar alguns exemplos. Bilac não tomou parte direta na criação, em 1908, da então Associação da Imprensa, alguns anos depois rebatizada Associação Brasileira de Imprensa, e que assim será referenciada aqui. Entretanto, não seria exagero argumentar que o jornalista estava profundamente inteirado das demandas contempladas pela iniciativa.

A ABI foi formalmente fundada em 7 de abril de 1908. Três dias antes, Olavo Bilac havia remetido para o Correio Paulistano, no qual escrevia como colaborador, uma crônica sobre a história de um repórter desassistido após sua demissão de um jornal. As tragédias que o acometeram foram diretamente conectadas, pelo cronista, ao fato de o repórter ter se achado desprotegido e caído em situação de profunda vulnerabilidade social, em muito pela falta de uma organização de classe que pudesse lhe prover algum amparo. A crônica foi publicada no dia seis de abril e nela ele argumentava:

O Rio, São Paulo, todas as cidades principais do Brasil possuem sociedades de assistência e beneficência para cada classe de trabalhadores. Não há estivador, nem sapateiro, nem pedreiro, nem alfaiate, nem operário de qualquer especialidade, que não tenham, em caso de moléstia passageira, ou de invalidez irremediável, a sua caixa de pensões, seu hospital, o seu amparo de mutualidade. Só não tem isso o rabiscador de notícias e de artigos. É este proletário mais infeliz, mais privado de socorro na moléstia e na velhice.

$[\ldots]$

Ainda há pouco tempo, vivia no Rio um desses mártires do jornalismo; adoeceu, ficou imprestável, foi atirado à rua como um trapo, e começou a viver de favores, passou a viver de esmolas, e amanheceu morto, um dia, deitado num banco de jardim público, que era a sua cama, sob o céu amplo que era o teto da sua casa. [...] Ao cabo de cinco, ou dez, ou quinze anos de trabalho, um empregado de casa comercial tem um interesse nos lucros da loja, passa a ser sócio do patrão, prospera, torna-se independente, assegura contra a fome e a cova rasa a sua velhice e o seu cadáver.

[...]

Mas de nós mesmos é que podemos exigir alguma cousa: alguma previdência, algum cuidado, alguma compreensão da virtude das vantagens do sistema da mutualidade. ${ }^{29}$

O narrador ainda arremataria, na mesma crônica, que caberia então aos jornalistas se mobilizarem, à exemplo mais uma vez dos franceses, para organizar uma mutual. De fato, uma das finalidades centrais da Associação

\footnotetext{
${ }^{28}$ Idem. Ver esp. o capítulo Pauta dos jornalistas. Para um estudo sobre A Bruxa dedicado com mais vagar ao trabalho de Julião Machado, ver FONSECA, Letícia Pedruzzi. Uma revolução gráfica: Julião Machado e as revistas ilustradas no Brasil (1895-1898). São Paulo: Blucher, 2016.

${ }^{29}$ Diário do Rio. Correio Paulistano, São Paulo, 6 abr. 1908, p. 1.
} 
Brasileira de Imprensa ${ }^{30}$, oficialmente fundada três dias após Bilac escrever essa crônica, seria justamente de caráter mutualista. A partir dela criou-se também o Retiro da Imprensa, posteriormente rebatizado Retiro dos Jornalistas, que abrigaria àqueles que encerrassem suas atividades na profissão e necessitassem de amparo, seja por questões de invalidez ou velhice. Entre outras iniciativas, a ABI ainda pretendia criar algum controle sobre a profissão e declarava querer "habilitar, por meio de título de capacidade intelectual e moral, o pretendente à colocação no jornalismo". ${ }^{31}$

A origem da associação importa e se revela significativa já na ocasião de sua fundação. Ela foi gestada entre um grupo pequeno de jornalistas, apesar dos seus esforços em engajar mais sujeitos, e efetivamente fundada na sala onde funcionava a caixa de beneficência dos empregados do jornal O País, veículo no qual trabalhava seu principal idealizador, o jornalista negro, socialista e profundamente ligado ao movimento de trabalhadores do Rio de Janeiro, Gustavo de Lacerda. ${ }^{32}$ Talvez isso seja fator a se considerar diante da pouca adesão à iniciativa, no momento da criação da associação. De todo modo, seja quais fossem os critérios ou quais fossem as organizações, relembrando a tentativa circunscrita da criação do Club dos Jornalistas, é possível afirmar que Olavo Bilac estaria apto para tomar parte em qualquer uma delas, como jornalista e trabalhador da imprensa.

A primeira vez que Bilac assumiu um posto na redação de um jornal diário foi em 1893, na Cidade do Rio. Foi também apenas nesse momento, de posse de um cargo nos escritórios do jornal de José do Patrocínio, que ele de fato começou a ser referenciado no Almanak Laemmert como jornalista ${ }^{33}$, mesmo que já se ocupasse da imprensa há alguns anos. Ele havia sido, inclusive, enviado à Europa como correspondente internacional para esse mesmo jornal, em 1891. Nesse período, as indeterminações da profissão do jornalista eram muitas, a um só tempo comportava estruturação e mudança, e muitas das funções nas redações dos diários eram exercidas sem divisão específica. Bilac produziu uma crônica tratando justamente dessas muitas tarefas que cabiam a um jornalista, o que denotava seu conhecimento detalhado sobre as rotinas da imprensa diária. As atribuições iam de cobrir os debates parlamentares a receber as notícias na bancada dos escritórios, para além da produção dos textos e notícias variados que ganhariam as páginas das folhas. Sem meias-palavras, a crônica se intitulava "Sem nervos". ${ }^{34}$ Afinal, na opinião do cronista, essa seria a única maneira de um jornalista suportar a rotina extenuante e múltipla da profissão. Vale, portanto, seguir não só a pena, mas também os passos de Olavo Bilac nos veículos de imprensa em que se empregou, com vias de perceber algumas das nuances de seu trabalho.

\footnotetext{
${ }^{30}$ Cf. Associação da Imprensa. O País, Rio de Janeiro, 8 abr. 1908, p. 1; Associação Brasileira de Imprensa. Estatutos. Rio de Janeiro: Benedicto de Souza, 1926.

${ }^{31}$ Associação de Imprensa, op. cit.

${ }^{32}$ Cf. PINTO, Ana Flávia Magalhães. Vicente de Souza: intersecções e confluências na trajetória de um abolicionista, republicano e socialista negro brasileiro. Estudos Históricos, v. 32, n. 66, Rio de Janeiro, jan.-abr. 2019.

33 Ver Almanak Administrativo, Mercantil e Industrial do Rio de Janeiro, 50. ano, 1893, p. 316.

${ }^{34}$ Sem nervos. Gazeta de Notícias, Rio de Janeiro, 11 jun. 1895, p. 1.
} 
Em 1894 os registros do jornalista já não apareciam com seu endereço profissional referenciado na rua do Ouvidor, 74, onde se localizavam os escritórios da Cidade do Rio, mas sim no número 70 da mesma rua, dos escritórios da renomada Gazeta de Notícias. ${ }^{35}$ No ano seguinte, seu endereço profissional permaneceria o mesmo, indicando a continuidade na redação da Gazeta, acrescido do registro de seu endereço residencial, na rua D. Marciana, número 32. Uma pesquisa detalhada sobre esse endereço no próprio Almanak Laemmert revelou ser uma rua residencial prestigiada, habitada por engenheiros, médicos, engenheiros arquitetos e funcionários públicos em altos cargos, no bairro de Botafogo. Na mesma rua também se localizava o colégio Rampi Williams, uma importante escola exclusiva para crianças do sexo feminino, frequentada pelas filhas da elite carioca.

O ano de 1895 seguiu bastante promissor na carreira de Bilac, o que se revela não apenas pela permanência no local em que residia, mas também pelo fato de, para além do cargo na redação da Gazeta, ele continuar a produzir como colaborador para muitos veículos, destacando-se entre eles o diário $A$ Notícia, do qual se tornaria redator anos mais tarde. Além disso, foi nesse ano que ele iniciou um projeto pessoal de destaque, uma revista ilustrada de bastante repercussão, junto a Julião Machado e sob administração de Manoel Ribeiro Júnior. A Cigarra, do qual era redator-chefe, durou apenas aquele ano e causou enorme barulho por conta do humor e sátira agudos que vertiam de suas páginas. O tom custou a Bilac seu cargo e certa indisposição no meio político e literário, de modo que o semanário não se manteve no ano seguinte, quando o experimentalismo de Bilac e Julião Machado se renovaria em outra empreitada.

1896 foi o ano em que a dupla renovou a parceria através da já citada revista A Bruxa, uma nova publicação semanal vastamente ilustrada e de acabamento bastante refinado, vendida pelo valor avulso de 1\$000 (mil réis), o que podia indicar alguma pretensão em circular em extratos mais altos da população da capital, para além de seu alto custo de produção. ${ }^{36}$ Nesse ano, Bilac manteve seu trabalho na redação da Gazeta de Notícias e, entre colaborações para periódicos diversos, também emplacou um folhetim na própria Gazeta, numa série feita com seu companheiro Julião Machado, intitulada Revista do ano de $1895 .{ }^{37}$ Apesar da prosperidade, mudou-se para uma rua menos prestigiada, ainda no bairro de Botafogo, a Fernandes Guimarães, número $45 \mathrm{~A} .{ }^{38}$

Já o ano de 1897 trouxe mudanças profissionais importantes para Bilac, que deixou de ter em seus registros o endereço profissional da Gazeta de Notícias, ainda que tenha assumido nesse ano o lugar de Machado de Assis na crônica dominical “A semana”. É possível afirmar, portanto, que seu próprio regime de trabalho tenha sido alterado, tornando-se um colaborador como tantos outros literatos do período. Também é possível perguntar-se, ainda, se tais mudanças foram fruto de um investimento do jornalista, que agora tinha na

\footnotetext{
${ }^{35}$ Ver Almanak Administrativo, Mercantil e Industrial do Rio de Janeiro, 51. ano, 1894, p. 345.

${ }^{36}$ Cf. FONSECA, Letícia Pedruzzi, op. cit., e SIMÕES JÚNIOR, Álvaro Santos. A crônica de Bilac em "A Bruxa" (1896-1897). Revista da Anpoll, v. 1, n. 38, Campinas, 2015.

${ }_{37}$ Revista do ano de 1895. Gazeta de Notícias, Rio de Janeiro, 6 jan. 1896, p. 1.

${ }^{38}$ Cf. Almanak Administrativo, Mercantil e Industrial do Rio de Janeiro, 53. ano, 1896, p. 387.
} 
rua do Ouvidor, número 118, seu endereço profissional, os escritórios de sua revista ilustrada semanal, $A$ Bruxa ${ }^{39}$ Eles se localizavam no térreo de um sobrado que tinha, em seu andar superior, os negócios do arquiteto e professor da faculdade de Belas Artes, Henrique Bahiana.

Diante dessas movimentações, também ocorreu uma mudança perceptível no padrão de moradia de Olavo Bilac. Se os escritórios d'A Bruxa alcançaram o centro nevrálgico do mundo das letras e da imprensa na capital, agora ele residia na Freguesia de São Cristóvão, na rua Conde do Bomfim, número 225 , no então afastado bairro da Tijuca. ${ }^{40}$ Era uma rua bastante comercial, povoada de açougues, lojas de aluguel de carruagens, lojas de ferragens e entre seus vizinhos residenciais encontravam-se de médicos a mestres de obras.

No ano seguinte, contrariando as possíveis apostas do jornalista, sabese que A Bruxa teve as atividades encerradas e Bilac viveu os meses subsequentes sob o ritmo da frenética rotina da colaboração na imprensa, mantendo-se no endereço da Tijuca, de onde só se mudaria após assumir uma posição na redação d' $A$ Notícia. Ali ele começou como redator no ano de 1899 e não tardou para que, de posse do novo trabalho fixo, mudasse de endereço, o que apareceria na edição do Almanak Laemmert de $1900 .{ }^{41}$ Agora ele moraria no bairro do Catete, próximo à Botafogo, na travessa Guaratiba, número 1, e permaneceria na redação d'A Notícia até 1905 . Nesse entremeio, pode ser que tenha se cansado de viver entre os sabores e instabilidades da imprensa, cavando, ainda no ano de 1901, o cargo de inspetor de ensino. Essa mudança teve grande impacto na vida profissional de Olavo Bilac, que se dedicaria profundamente ao tema da instrução até a data de sua morte, em 1918.

Mesmo correndo o risco de se tornar enfadonho, esse apanhado, entre residências e redações que povoaram os deslocamentos de Bilac pelo Rio de Janeiro, dão indícios de como regimes distintos de trabalho, principalmente nos jornais diários, impactavam de maneira significativa a vida de um reconhecido literato do período. Enquanto fazia parte da redação dos jornais, as possibilidades de Olavo Bilac pareceram mais promissoras e estáveis, tanto que tornaram possível que ele se aventurasse junto à Julião Machado no projeto de fundação d'A Cigarra e d'A Bruxa. Os hebdomadários eram o principal formato pelo qual os homens de letras optavam ao aventurarem-se em projetos pessoais, sobretudo a partir da década de 1890. E foi justamente nessas duas revistas ilustradas que Olavo Bilac escreveu com maior liberdade, tomando pelas mãos temas polêmicos que lhe renderam desconfianças e a pecha de militante, mas ali ele era diretor da redação, seu próprio redator-chefe.

Nessas empreitadas pessoais, sempre contando em regime de colaboração com amigos destacados do mundo das letras como Coelho Neto, Valentim Magalhães, Gastão Bousquet ou Eduardo Guimarães, Bilac vestiu-se de personagens múltiplas e fez defesa cerrada dos que escreviam, seja no terreno das casas editoriais, seja nas empresas jornalísticas. As revistas não vingaram e o retorno aos escritórios dos jornais diários sempre se impôs, até o momento em que se estabeleceu no funcionalismo público e em altos cargos relativos à

\footnotetext{
${ }^{39}$ Cf. Almanak Administrativo, Mercantil e Industrial do Rio de Janeiro, 54. ano, 1897, p. 529.

${ }^{40}$ Cf. idem.

41 Ver Almanak Administrativo, Mercantil e Industrial do Rio de Janeiro, 57. ano, 1900, p. 540.
} 
instrução pública. Nesse momento, aliado ao desgaste enfrentado na empreitada de fundação de uma agência de notícias nacional, ele deixou a imprensa, em 1908. Entretanto, sua trajetória permite acompanhar os regimes distintos de trabalho que nela operavam e como impactavam o cotidiano dos literatos. Bilac transitou por todos esses modos de produzir jornalismo e literatura na imprensa, com grande fluência.

\section{“O jornalismo, especialmente no Brasil, é um fator bom ou mau para a arte literária?"}

É essencial assinalar que a atividade literária mais disposta ao ambiente dos jornais, entre o fim do século XIX e início do século XX, era a crônica, e sua constante capacidade de adaptação aos novos ritmos da imprensa se deu de tal modo que conquistou prioridade inclusive na pena de um poeta. Por outro lado, esse novo jornalismo, agora organizado também em empresas e pautado por interesses comerciais pronunciados, foi restritivo a muitos literatos, para literatas especialmente, e para aqueles com projetos que confrontassem, quem sabe, tal mercantilização.

Olavo Bilac foi exemplo de quem transitou com desenvoltura por esse mundo e acompanhá-lo é poder entender melhor parte da imprensa republicana em suas primeiras décadas. Foi na redação dos grandes diários do Rio de Janeiro que ele encontrou estabilidade financeira, ao passo que sempre teve espaço, de forma generalizada, para emplacar suas colaborações desde a década de 1890, assumindo inclusive a crônica dominical "A semana", herdada de Machado de Assis em 1897. Assim, entre o trabalho cotidiano de redator nos escritórios dos jornais, a fundação de periódicos próprios e os regimes de colaboração eventual, para folhas variadas, têm-se um número imenso de textos publicados por Bilac, o que faz jus ao reconhecimento que recebia no mundo literário do início dos novecentos. É justamente por sua profusão como cronista, inclusive, que ele é tomado como jornalista por Antonio Dimas, que produziu trabalho absolutamente central sobre a crônica bilaquiana. Entretanto, é importante enfatizar que havia distância a ser considerada entre o fazer do cronista e do jornalista, que muitas vezes podiam se cruzar, como parte do mundo do trabalho nas redações, mas não como via de regra. O próprio Bilac notou, em crônica, alguma separação de ofício:

Há dias, um jornal, apelando para o espírito de justiça do prefeito, foi pedir a ele que delatasse o prazo concedido aos proprietários para a pintura das fachadas dos seus prédios, - "por não haver na cidade pintores bastantes para tão grande trabalho".

A razão alegada é interessante. Não convém que isso fique perdido, sem comentário, nas cúrias linhas de uma reclamação escrita às pressas. Os noticiaristas registram; os cronistas comentam. O noticiarista retira da mina a ganga de quartzo, em que o ouro dorme, sem brilho e sem préstimo; o cronista separa o metal precioso da matéria bruta que o abriga, e fazes esplender ao sol a pepita rutilante. Naquela notícia e naquela razão há um lindo pedaço de ouro que convém aproveitar... ${ }^{42}$

${ }^{42}$ Crônica. Gazeta de Notícias, Rio de Janeiro, 21 jul. 1903, p. 1. 
Diante da declaração do trabalho de ourivesaria que emergia no fazer do cronista, convém retomar o inquérito de João do Rio: “O jornalismo, especialmente no Brasil, é um fator bom ou mau para a arte literária?".

Olavo Bilac foi entrevistado em sua casa, mas antes de João do Rio revelar precisamente as respostas ao inquérito, ele trazia um longo comentário feito pelo poeta, revelando alguém que compreendia sua relação com o ofício de escrever sob uma perspectiva plenamente conectada com o mundo em que vivia:

A Arte não é, como ainda querem alguns sonhadores ingênuos, uma aspiração e um trabalho à parte, sem ligação com as preocupações da existência. Todas as preocupações humanas se enfeixam e misturam de modo inseparável. As torres de ouro e marfim, em que os artistas se fechavam, ruíram desmoronadas. A Arte de hoje é aberta e sujeita a todas as influências do meio e do tempo: para ser a mais bela representação da vida, ela tem de ouvir e guardar todos os gritos, todas as queixas, todas as lamentações do rebanho humano. ${ }^{43}$

Entre os escombros das torres de ouro e marfim emergia o jornalista e o literato, figuras que não são redundantes, mas capazes de lidar, cada uma a seu modo, com a vida cotidiana, como notícia ou como arte, caminhando ao rés do chão. Diante disso, as considerações sobre os benefícios do jornalismo sobre a literatura tornam-se mais específicos, apesar de seus ares de universalidade e um misto de reconhecimento e melancolia:

O jornalismo é para todo o escritor brasileiro um grande bem. É mesmo o único meio do escritor se fazer ler. O meio de ação nos falharia absolutamente se não fosse o jornal - porque o livro ainda não é coisa que se compre no Brasil como uma necessidade. O jornal é um problema complexo. Nós adquirimos a possibilidade de poder falar a um certo número de pessoas que nos desconheceriam se não fosse a folha diária; os proprietários de jornal veem limitada, pela falta de instrução, a tiragem das suas empresas. Todos os jornais do Rio não vendem, reunidos, cento e cinquenta mil exemplares, tiragem insignificante para qualquer diário de segunda ordem na Europa. São oito os nossos! Isso demonstra que o público não lê - visto o prestígio representativo gozado pelo jornalista.

$[\ldots]$

“Oh! sim, é um bem. Mas se um moço escritor viesse, nesse dia triste, pedir um conselho à minha tristeza e ao meu desconsolado outono, eu lhe diria apenas: Ama a tua arte sobre todas as coisas e tem a coragem, que eu não tive, de morrer de fome para não prostituir o teu talento!"44

Entre lamentos e diagnósticos, Olavo Bilac foi uma figura de destaque em seu tempo, um homem de letras que alcançou grande renome e adentrou à imprensa tanto como literato, quanto como jornalista. Desse trabalho, como a análise estabelecida nesse artigo tenta colocar mais às vistas, dependia a estabilidade financeira de Bilac e dependia em grande medida sua circulação literária, ainda que ele ralhasse, melancolicamente, ter lhe faltado coragem para morrer de fome ao invés de prostituir seu talento. Assim, é possível afirmar

${ }^{43}$ DO RIO, João. O momento literário, op. cit., p. 8.

${ }^{44}$ Idem, ibidem, p. 10 e 11. 
que o jornalismo, ao menos no Rio de Janeiro de fins do Império e início da República, foi profundamente talhado pela ação de literatos que assumiram esse ofício, que conduziram como trabalhadores qualificados os escritórios da imprensa diária e comercial. É uma perspectiva que permite, passo a passo, deslocar os "rabiscadores de notícias e de artigos" 45 de um local de elitismo por si, e assim compreender a emergência de um mundo das letras ligado ao trabalho, que também engendrou homens e mulheres diferentes dos padrões de Olavo Bilac e Júlia Lopes de Almeida.

Não é por acaso que a ABI, fundada em 1908 pelo jornalista negro e socialista Gustavo Lacerda, iria abrigar de literatos e cartunistas a repórteres, funcionando como uma verdadeira e ampla mutual daqueles que trabalhavam na imprensa. O que é um importante capítulo desse mundo das letras.

Artigo recebido em 15 de dezembro de 2020. Aprovado em 20 de janeiro de 2021.

${ }^{45}$ Diário do Rio. Correio Paulistano, op. cit. 